\title{
Philip Roth, Portnoy og sentresserne
}

\author{
CLAUS SECHER
}

Mens en stor række af de toneangivende forfattere i 1960'ernes USA som Joseph Heller, Kurt Vonnegut, Richard Brautigan og Thomas Pynchon i postmoderne, eksperimenterende former skildrede deres land som et surreelt, absurdt mareridt, fortsatte Philip Roth i sit forfatterskab en mere indadvendt psykologisk realisme, der havde sine rødder i den jødiske tradition i amerikansk litteratur, der for alvor var slået igennem i 1950'erne med Saul Bellow og Bernard Malamud.1 Alligevel havde Roth fra forfatterskabets start med novellesamlingen Goodbye, Columbus fra 19592 vist et mere konfliktsøgende og satirisk talent, der blandt de mere konservative jøder i USA gav ham et image som "en dårlig jøde", antisemit og forræder imod sin egen baggrund. I Roths to efterfølgende romaner Letting Go fra 1962 og When She Was Good fra 1967.var den jødiske baggrund neddæmpet eller i den sidstnævnte ikke-eksisterende, samtidig med at han satsede på en alvorlig, psykologisk realisme, der borede sig ned i personernes traumer og utilstrækkelighed.

Portnoy's Complaint, 1969 (Portnoys genvordigheder, 1969) blev gennembrudsbogen i Roths forfatterskab. Det blev den største jødiske succesroman nogensinde og en af 60' ernes mest solgte. Den gjorde Roth til millionær og efterlod ham i dyb psykologisk krise. På godt og ondt determinerede den hele hans efterfølgende forfatterskab.

. Man tager næppe fejl, når man antager, at det er romanens seksuelle frisprog og først og fremmest de grotesk overdrevne 
onani-scener, der gjorde Portnoys genvordigheder til den skandalesucces, den blev. Det var også denne verbale frigjorthed, der forbandt forfatteren intimt med hans samtid, modkulturen i sentressernes USA. Men man tager grueligt fejl af bogen, hvis man læser den som pornografi og Roth som en skønlitteraturens Norman 0 . Brown eller Herbert Marcuse. I virkeligheden er Portnoys genvordigheder en sygehistorie fortalt i en fiktiv ramme, hvor Portnoy på psykiaterens briks fortæller sin livshistorie og om årsagerne til sit psykiske sammenbrud, før den egentlige terapi kan begynde.

Når Roth i sin specielle form for selvbiografi The Facts, 1988, med en vis ret kan tale om, at Portnoys genvordigheder er et barn af sentressernes oprørske og afmytificerende klima, så ligger oprøret ikke i romanens tematik, der ender med oprørets fiasko, men i selve dens tabub ${ }_{\mathrm{ry}}$ dende stil og dens maniske obskønitet. Det er helt præcist som Ruth R Wisse bemærker, at Portnoy er "en ordmager, hvis væsentligste oplevelse er $\operatorname{lin}_{\mathrm{g}}$ istisk. Bogens reelle onani er verbal, orgasmen er litterære klimakser".3 Mens Portnoy ender som en kastreret Ødipus på briksen, så sprøjter Roths verbale obskøniteter mod tekstens loft. Derved bliver bogen både morsom og samtidig dybt deprimerende, fordi den sproglige frigjorthed må leve sammen med en bevidsthed om, at frigørelsen ikke er mulig.

\section{Den psykoanalytiske monolog og den ødipale trekant}

Philip Roth arbejdede med Portnoys genvordigheder igennem det meste af 60' erne og eksperimenterede med 4 andre mulige former, inden han besluttede sig for den definitive: at lægge fortællingen i Portnoys egen mund, mens han ligger på psykoanalytikerens briks 4 - Romanens raffinerede tekniske pointe, der for førstegangslæseren først åbenbares på sidste side, er at hele Portnoys lange monolog om sit livs genvordigheder er en lang prolog, før den psykoanalytiske dialog kan starte.

Den psykoanalytiske monolog gav Roth en kunstnerisk frihed, han ikke hidtil havde haft, med en jeg-fortæller, der principielt er villig til at afsløre alt, også sine mest slibrige obskøne sider, for at komme ud af sine traumer. Når Roth egentlig ikke 
havde brug for psykoanalytikerens modspil, var det, fordi han havde valgt en hovedperson, der fuldt ud selv var i stand til at analysere sine problemer, hvilket ikke er det samme som at kunne løse dem. Alexander Portnoy går selv i seng med Freuds værker, og han ved både fra teori og sit eget liv, hvad der ligger i begreber som: Ødipus-kompleks, kastrationstrussel, oral fase, over-jeg, jeg og id, kulturens byrde etc. Således konstaterer Portnoy f.eks., at han ikke har brug for drømme, for hvad der i andre menneskers liv kan afsløres gennem analyse af det latente drømmeindhold, det sker i hans manifeste liv: „Jeg har et liv uden latent indhold. Drømmebegivenhederne sker". 5

Den psykoanalytiske monolog giver mulighed for at fokusere på det der er fundamentalt i psykoanalysen. Freud havde sex på hjernen, amerikanerne har det, Roth har det, og Alexander Portnoy har det i ekstrem grad. Den psykoanalytiske monolog baner -vejen for en sprængning af sproglige konventioner af både litterær og dagligdags art. Portnoy bryder med alle former for urbant sprog i en ekstremt obskøn og bevidst infantil talestrøm, der skal blotlægge alt, og romanen bryder med de former for højlitterær objektivistisk pænhed, som Roths to tidligere romaner med deres efterligning af mønstre fra Henry Jarnes og Gustave Flaubert . havde tilstræbt. Inspirationen til Portnoys genvordigheder er tydeligvis den rablende, gennemseksualiserede strearn of consciousness-teknik, man finder i det berømte slutkapitel i Joyces Ulysses. Selv om der selvfølgelig er tale om en roman og dermed et skriftsprog, så åbner denne romanform op for en efterligning af et bevidst vulgært talesprog. Overdrivelsen (hyperblen) er af de teknikker, Roth havde lært den fra de jødiske stand-up comedians som Lenny Bruce og Mort Sahl, og som han rendyrker i denne roman. For egentlig er Portrtoys liv - ligesom forfatteren har hævdet det om sit eget - ret udramatisk, men gennem Portnoys rablende retorik forstørres det op til mytiske proportioner.

Philip Roth lader altså Portnoys historie blive anskuet gennem en freudiansk optik; sygdomshistorien analyseres af den intellektuelle patient, men på et væsentligt punkt afviger Portnys foreløbige livshistorie fra klassik freudianisme, og det kommenteres ikke af den ellers $\mathrm{k}_{\mathrm{y}}$ dige jeg-fortæller. Hvor moderen $\mathrm{i}$ 
Sofokles' tragedie og Freuds analyse er det begærede objekt, og faderen rivalen, der ønskes ryddet af vejen, så er Sophie Portnoy i sønnens univers både den begærede og den lovgiver, der kriminaliserer begæret. Den seksuelle dragning bliver til væmmelse. Med afsky erindrer Alexander scener fra barndommen, hvor moderen tager strømper på og lader barnet føle på sine lårs faste ungdommelighed, eller scenen hvor hendes menstruationsblod løber ud på køkkengulvet, og han sendes i byen efter hygiejnebind.

I den klassiske ødipale trekant kommer kastrationstruslen fra faderen, rivalen, men i det Portnoyske familiedrama er moderen så stærk og faderen så svag, at den truende kniv svinges af moderen mod sønnen. Ganske vist drejer det sig om en brødkniv, og ganske vist vil moderen ikke skære hans lem af, men tvinge ham til at spise hendes jødiske mad (og ikke hamburgers og pommes frites), men i den voksne Freud-læsende søns erindring er der ingen tvivl om, at jødiske mødre vil kastrere deres sønner. Med et freudiansk begreb, som Roth lader psykoanalytikeren Spielvogel anvende i den senere roman My Life as a Man, 1974) (Mit liv . som mand, 1975), kunne man sige, at Sophie Portnoy inkarnerer „den falliske mor".

Portnoys far er - som Roths egen var det-forsikringsagent for et rigt WASP-ejet forsikringsselskab, og alle hans fremtidsdrømme er knyttet til, at sønnen skal udnytte de sociale opstigningsmuligheder i USA, som han ikke selv kunne realisere. (Sønnens fornavn, Alexander, peger netop på forældrenes drømme om sønnens storhed). Allerede som barn forstår sønnen det selvopofrende i faderens projekt, men kan ikke gengælde hans $ø$ mhed, fordi den skaber skyldfølelse. Som en komisk metafor for faderens uforløsthed $\mathbf{i}$ familien udstyreres han med afføringsproblemer, som gør badeværelset til centrum for de familiemæssige traumet. Hvis moderen ved sin stadige kredsen om mad forsøger at fastholde Portnoy på det orale stadium, så fikserer faderen ham på det anale. Intet under at Portnoy i denne familiekonstellation følelsesmæssigt forbliver infantil.

De få positive erindringer, Portnoy har om faderen fra barndommen er alle knyttet til dennes indgåen i en større jødisk man- 
deverden: det rituelle bad, aftener med soft-ball etc. Hans givetvis grundløse fantasi om faderens sidesping med en goyisk sekretær er et forsøg på at tildigte faderen en mere (beskidt) maskulin identitet. For Alexander er hovedproblemet i barndommen, at moderen er manden i hans familie og faderen kvinden: „Den, der burde skælde mig ud, fald $r$ hjælpeløst sammen, fuldkommen slået ud af sit bløde hjerte! $\mathrm{Og}$ den, der burde falde sammen, skælder ud i stedet for, retter på mig, kritiserer, dadler, finder fejl ved mig i det uendelige! Udfylder det patriarkalske vakuum!" (s.41f).

Opløsningen eller omvendingen af den traditionelle kønsopfattelse_i forbindelse med forældrefigurerne har givetvis en del at gøre med mere generelle ændringer i den vestlige familiestruktur, men har også, og det er den fortolkning, romanen lægger, en speciel baggrund i den jødiske kultur og dennes historiske udvikling. Jødedommen var nok en patriarkalsk religion, men det ideelle billede af manden i den klassiske østeuropæiske jødedom var ikke det hårde udvendige succesmenneske, men den mere bløde, åndeligtstræbende mand.6 Moderen skulle tilsvarende ofte ikke blot tage sig af hjemmet og opdragelsen og dermed være garant for at jødedommens ritualer gik i arv. Hun skulle også tjene til det daglige brød, f.eks. gennem en butik eller en stand på markedspladsen, så ægtemanden kunne hellige sig de religiøse studier. Moderens markante plads i den jødiske familie - det var og er jo via moderen man defineres som jøde - havde enorm indflydelse på socialiseringen af børnene, det var moderen der i hverdagen sørgede for overholdelse af de mange regler og påbud, f.eks. om kosher-maden, og oplevelsen af faderen som religiøs intellektuel betød et anderledes mandebillede for den jødiske $\varsigma ø$.

I forbindelse med den store indvandring af mere end 2 millioner jøder fra Østeuropa til US A i perioden 1880-1914 har Irving Howe i World of Our Fathers, 1976 fremhævet sønnernes dårlige forhold til deres fædre i de jødiske immigrantfamilier. De så ned på deres fædre på grund af disses ofte lave sociale status, dårlige engelsk og usikre kulturelle identitet, og mødrene fik derfor den centrale plads i socialiseringen af børnene. 
Portnoy tilhører lige som sin forfatter en senere generation. Indvandrergenerationen er bedsteforældrenes; men historien gentager sig i den forstand, at den unge generation, der vokser op efter 2. Verdenskrig og for hvem verden står åben, ser ned på sin lavere middelklasse (white collar)-baggrund) og dermed faderen, samtidig med at den jødiske søn må tage demonstrativt afstand fra den figur, der repræsenterer de klassiske jødiske forbud og leveregler: moderen.

Forfatteren Isaac Rosenfeld har i essayet "Adam and Eve on Delancey Street" argumenteret for sammenhængen mellem kosher-reglerne og tabuiseringen af sex i den jødiske familie.7 Ved at referere til madreglerne kunne forældrene (primært moderen) indirekte stadfæste de seksuelle forbud. Fordømmelsen af det urene (treif) kunne anvendes samtidig på begge planer. Denne sammenhæng er også tydelig i Portnoys genvordigheder, hvor moderen både lovgiver om hvad der er kulinarisk og seksuelt tilladeligt, og hvor Portnoys vildere og vildere overskridelser af forbudene breder sig fra maden til det seksuelle. I den groteske scene, hvor Portnoy onanerer i et stykke lever falder planerne farceagtigt sammen.

Når holdningen til den jødiske mor på 1960'ernes kulturelle scene ændres fra øm respekt til komisk udlevering, har det selvfølgelig noget at gøre med det antiautoritære ungdomsoprør. Det var ikke Philip Roth, der opfandt de komiske muligheder i den jødiske mor-skikkelse. Filmene, teatret og stand-up comedians havde allerede udnyttet de komiske potentialer, og jødisk-amerikanske forfattere som Herbert Gold, Bruce Jay Friedmann og Wallace Markfield havde gjort det samme. Men med Roths eller mere præcist Portnoys portræt blev skikkelsen unægteligt sat på spidsen. En tragikomisk varaint af temaet jødiske mødre og sønner giver Portnoy med historien om nabodrengen, den håbefulde pinanist, der pludselig begår selvmord ved at hænge sig under bruseren i badeværelset. På sin "nydelige stivede og renvaskede sportsskjorte" har han med en năl fæstnet følgende besked til moderen: „Fru Blumenthal har ringet. Jeg skulle bede dig tage mahjong-reglerne med i aften. Ronald." (s.115) Roth er ikke bange for at drive sit portræt af den "jiddische mama" ud i karikaturen. 
En særlig jødisk variant af familieundertrykkelsen er - som Portnoy oplever det - forældrenes og den artige søsters mobilisering af den jødiske historie og først og fremmest Holocaust-erfaringen som socialiseringsinstrument, hver gang Alexander gør sig ud til bens. "Nazisterne kan vel bruges som undskyldning for alt, hvad der sker her i huset!" (s. 74) er Alexanders reaktion, da forældrene vil tvinge ham med i synagogen. Portnoy udvikler eri sensibilitet over de manipulationsmuligheder der ligger i den tidligere offer-rolle, og gennemskuer også den følelse af mereværd, der ofte ligger i Newark-jødernes kritik af ikke-jøderne (goyim). I liberalismens navn opponerer han mod deres behandling og nedladende omtale af de sorte.

\section{Onanismens Raskolnikov og shikserne}

Det er i onani-scenerne, at Roth driver romanen ud i de største farceagtige overdrivelser. Hovedparten af dem foregår i familiens badeværelse med forældrene hamrende på den låste dør. Portnoys maniske onani er ikke bare et biologisk behov, men også et kulturelt oprør mod den jødiske pænhed og samvittighed: "Doktor, kan De forstå, hvad jeg stod overfor. Min tissemand var i virkelighed det eneste, jeg kunne kalde mit eget." (s. 33) Portnoys problem er blot, at det moderlige forbud, han gør oprør imod, allerede befinder sig inde i hans eget hoved som et over-jeg. Derfor bliver enhver overskridende onani-scene kun en uddybelse af hans egen skyldfølelse, og det er således ikke helt uden grund, at han med vanlig overdrivelse udnævner sig til "onanismens Raskolnikov". Ligesom Dostojevskijs romanfigur erfarer den jødiske, seksuelle desperado, at han har et langt mere tvetydigt forhold til sin samvittighed, end han egentlig forestillede sig.

Det infantile i onaniscenerne og den tvetydige holdning til sin jødiske baggrund viderefører Portnoy i sin psykoseksuelle udvikling. Som ung drages han mod de rigtige amerikanske piger, shikserne. Også her antager seksualiteten karakter af et program, for som han (jødedrengen) siger på briksen: ${ }_{11}$ Jeg vil opdage Amerika ved at kneppe. Erobre Amerika - det er måske snarere sagen" (s. 221). 
Portnoys første shikse, Kay Campbell, kaldet "græskarret", er idealet af en ung, sund, idealistisk amerikansk pige, men i hen.des rige og gæstfri hjem føler han pludselig dårlig samvittighed over for sine forældre, og da hun tror sig gravid, bliver han pludselig fornærmet over at hun ikke vil skifte til den jødiske religion, som han hidtil kun har næret foragt over for.

Den anden shikse, Sally, rigmandsdatter fra Connecticut, tvinger han til fellatio (hans store besættelse) for derefter at forlade hende med den indre motivering, at han nu har hævnet, den måde hans far er blevet undertrykt på af hendes artsfæller. Det er således et af Portnoys mange paradokser, at han bruger shikserne for at flygte fra sin jødiske baggrund og blive integreret $\mathrm{i}$ WASP-kulturens USA for senere at $b_{\mathrm{r} y}$ de ved at insistere på sin jødiskhed. Samtidig med at han psykisk spaltes i forhold til det seksuelle, det jødiske hoved må forkaste hvad den assimilerede pik gør.

Tydeligst kommer denne spaltning frem i hans forhold til „Aben", hvis lidet smigrende øgenavn stammer fra en betroelse, iflg. hvilken hun som tilskuer i sin noget tvivlsomme fortid til et vennepars kopuleren valgte at spise en banan. Denne overtydelige falliske symbolik er guf for en Portnoy, hvis drøm er fellatio, men hvis jødiske over-jeg må fordøn.une den kvinde, som vil tilfredsstille den. Aben er for ham den realiserede pubertetsdrøm om ubegrænset seksuel lyst, samtidig med at hendes sociale historie som mishandlet proletarbarn appellerer til hans intellektuelle ambitioner om at kæmpe for de undertryktes sag.

$\mathrm{P}_{\text {_ }}$ det tidspunkt de mødes har han skabt sig et image som progressivjurist, der arbejder for ligestilling og taler de smås sag, men samtidig er Aben med sit udfordrende udseende og sin åbenbare mangel på dannelse en trussel mod hans politiske karriere. Portnoy gennemskuer klart, at han som andre "lænestolssocialister" i praksis foragter det folk, han i teorien går i brechen for. Og denne foragt udspringer præcist af, at han inderst inde som artig lille jødedreng ikke tør præsentere sine forældre for en kommende svigerdatter, der repræsenterer alt det vulgære i Amerika, som jødiske forældre foragter. 
Forholdet kulminerer på en Europa-rejse, da Portnoy tvinger Aben ind i et trekants-orgie med en romersk luder. Portnoy brækker sig bagefter i wc-kummen, og Aben føler sig ydmyget både som potentiel luder og lesbisk. Portnoy stikker af med flyveren til Israel, mens han i sit indre visualiserer hendes hævn enten gennem selvmord eller ved at afsløre hulheden i hans progressive image i de amerikanske medier.

\section{Shlemieleri og den jødiske Don Juan}

Det Israel, Roth lader Portnoy møde i romanens sidste kapitel er kibbutzernes og Arbejderpartiets Israel, baseret på fællesskabsfølelse, kollektive ejendomsret og hårdt slid og et ideologisk opgør med diaspora-jødens blødhed og passivitet. I konfronta tion med dette lands stærke kvinder møder Portnoy sit endelige nederlag og nervøse sammenbrud. I to meget parallelle scener prøver han at forføre eller voldtage to israelske piger, først en kvindelig løjtnant, siden en idealistisk, men benhård kibbutzpige, Naomi, hvis fysiske lighed ikke blot med Græskarret, men med hans mor for alvor gør ham impotent. Portnoy magter ikke at forbinde sig med jødisk sundhed, og da slet ikke med en pige, der får hans voldtægtsforsøg til at ligne en realiseret blodskamsfantasi. Den kastrerede Ødipus har med denne skrækvision nået -sit absolutte eksistentielle nulpunkt og kan afslutte sin monolog med et fem liniers langt primalskrig. Med det slutter romanen. Og den tavse dr. Spielvogel kan nu "muske beginne" den terapeutiske dialog.

I scenen hvor Portnoy forsøger at voldtage Naomi, kalder hun ham foragteligt: ,,Shlemiel" (s. 250). Ordet stammer fra den østeuropæiske, jiddisch-sprogede kulturtradition og betegner en ulykkesfugl, der altid kommer galt af sted, men som overlever, fordi han har humøret og sin menneskelige værdighed i behold. Han er en meget dominerende $\mathrm{fi}_{\mathrm{g} \text { u }}$ både i den jiddische mundtlige tradition og i den jødiske litteratur. For Naomi er shlemielbegrebet imidlertid forbundet med den gamle diaspora-kultur, hun foragter, hvor jøderne var "skræmte, altid i defensiven, kastrerede og korrumperede af livet i den ikke-jødiske verden" (s. 250). Det var denne diaspora-kultur, der havde forårsaget, at jø- 
derne uden at løfte en hånd i millionvis var gået ind i gaskamrene, og som det nye Israel må distancere sig fra. I Portnoys kyniske selvironi, hans narcissisme, og reelle selvhad genfinder hun diaspora-jøden.

Portnoys dilemma, der gradvis vokser til psykisk sammenbrud, er at han på den ene side gør oprør mod de jødiske forældres småborgerlige puritanisme, men samtidig har inderliggjort deres normer, således at det ikke kun er ydre instanser (forældrene, Aben, Naomi), men også hans indre samvittighed, der dømmer ham. I to drømme i romanen ser Portnoy sig dømt, først af djævelen, der senere viser at være hans barndoms rabbi (s. 193), senere af en dommer, der dømmer ham til impotens, fordi han bag en maske af liberalitet har nedværdiget og ydmyget et af de mennesker, han burde forsvare (Aben, s. 2561). At både rabbineren og dommeren er manifestationer af det Portnoyske overjeg er åbenbart, og selv om Portnoy mener, at hans synder er små, så er det den jødiske samvittighed, som sejrer og fremtvinger hans mentale sammenbrud. Det er i disse to drømme- og domsscener, at inspirationen fra en anden, ældre jødisk forfatter Franz Kafkå, er tydeligst, men selvfølgelig Kafka skrevet om til jødiskamerikansk farce.s

Portnoy kalder ikke sig selv for en Don Juan, og han er jo bogens eneste stemme. Men han kalder sig selv en "jødisk desperado" (s. 81), og hans seksuelle frigørelsesprojekt, hans ønske om at opdage Amerika ved at kneppe er i hvert fald en Don Juan værdigt, men i modsætning til den rigtige, der dømmes af religionens og moralens stengæst, så straffes Portnoy, fordi han mod sin vilje har internaliseret moderens normer. Straffen for den jødiske desperado er ikke det katolske Inferno, men et helvedes dårligt liv, et psykisk sammenbrud og en placering på psykoanalytikerens briks.

\section{Portnoy, sentresserne og kritikkerne}

Reaktionerne på Portnoy's Complaint fra de mere konservative amerikanske jøder var endnu kraftigere end i forhold til Goodbye, Columbus. Til begreberne selvhader og jødisk antisemit knyttedes opfattelsen af Roth som en blasfemisk krænker af både den jø- 
diske historie og den jødiske familie. Det almindelige publikum læste bogen som en dårligt maskeret selvbiografi, og Roths image blev fremover identificeret med Portnoys seksuelle udskejelser, og han blev betragtet som en dårlig jødisk søn, der havde udleveret sine stakkels forældre til spot og hånlatter.

Også i den mere seriøse akademiske kritik, skrevet af jødisk intellektuelle, kan man tydeligt spore en negativ reaktion. Her skal primært fremhæves Irving Howes kritiske essay ${ }_{\text {"Philip }}$ Roth reconsidered", oprindeligt offentliggjort i Commentary, december 1972.9 Iflg. Howes genvurdering viser Portfwy's Complaint for alvor Roths begrænsninger. Bogens metode er iflg. Howe ${ }_{\text {} t}$ the skit", den korte satiriske sketch, som Roth har lært fra "the stand-up comedian". Hvad Roth mangler er det, der kendetegner en stor romanforfatter: kærlighed til personer og historier og evnen til at levendegøre andre end hovedpersonen.

Howe ser Roth som et tidstypisk fænomen, en forfatter der skriver til de yngre jøder, der er trætte af al den snak om jødisk arv, og som har taget bogen til sig som et udsagn om "letting go", om det rigtige i at slippe driften og lysten løs. Howe selv havde rødder i 30ernes trotskistiske socialisme (og ikke psykoanalyse) og var generelt kritisk over for den dominerende seksualpolitiske komponent i det nye venstre i ungdomsoprørets USA. Så kritisk at han ganske overser, at Portnoy er alt andet end repræsentant for en glad seksuel revolution, og romanen som helhed ikke er noget lystigt budskab om den seksuelle frigørelses velsignelser.10

Fælles for den ældre generation af jødiske kritikere er opfattelsen af Roth som kold, selvcentreret og uden forståelse for værdierne i den jødiske familie og uden pietetsfølelse for jødernes historie, først og fremmest Holocaust. Han blev derfor opfattet som del af 60' ernes modkultur, der også havde et stærkt jødisk isiæt, men som mange af den ældre generation tog afstand fra af flere grunde, bl.a.på grund af den unge generations seksuelle løssluppenhed, dens moralske uansvarlighed og manglende positive jødiske identifikationsfølelse.

Det skulle vist fremgå af min læsning af Portnoys genvordigheder, at jeg ikke på samme måde opfatter den som entydig fiktiv 
iscenesættelse af typiske 60' er-holdninger. For det første var Roth født i 1933 og altså højt oppe i trediverne, da bogen kommer. Han starter som nævnt sin forfatterkarriere i sidste halvdel af 1950 ' erne, hvor novellerne begynder at komme i tidsskrifter, og i hans fiktion, essays og erindringer etabeleres hurtigt en opfattelse af 1950'erne som en alvorlig, småborgerlig og konform periode, der ikke kan undgå at præge ham. Det oprørske og modkulturelle i Portnoys genvordigheder ligger i sproget (hyperblerne og obskøniteten), i revolten mod forældrene, i satsningen på det infantile og det seksuelle. Men selvcentreringen, oprørets begrænsning og tydeligt neurotiske karakter og det faktum, at romanen er en selvbiografisk sygejournal sætter i høj grad spørgsmålstegn ved i hvor høj grad, Roths ærinde falder sammen med modkulturens. Romanens sorte humor og kunstneriske styrke hænger for mig at se sammen med, at begge dimensioner fastholdes.

(Det vil føre for vidt her at gå i dybden med problemstillingen, men for mig er der ingen tvivl om, at forestillingen om den seksuelle frigørelse i 1960'erne både var en realitet og en del af myten om 60'erne. I forhold til 50' erne og måske hele forældregenerationens tavshed og ofte bornerthed og i udviklingen af prævention skete der givetvis et spring, men i forhold til andre epoker i den vestlige historie mener jeg ikke, at "60'erne" var specielt "frigjort". Derudover ligger der også en lang diskussion i hele problemstillingen om hvad frigørelse egentlig er, og hvad der er etisk og menneskeligt ønskværdigt, og om begrebet "fri sex" giver mening. Det komplekse heri er i hvert fald bedre anskueliggjort i Portnoys genvordigheder end i Herbert Marcuses og Norman 0 . Browns seksualfilosofiske skrifter).

Læser man Portnoys genvordigheder i dag i sammenhæng med det ret fyldige forfatterskab, der fulgte efter, er det klart, at specielt den roman fik skelsættende betydning for hele Roths personlige og litterære udvikling. Oven på reaktionerne på bogen fik han et nervøst sammenbrud. For inderst inde var han ligesom Portnoy en hudløs, artig jødisk dreng, og som mange satirikere „en skaldesmækkende mimose". 
I den stadigt voksende serie om den jødiske forfatterskikkelse Nathan Zuckerman, ${ }^{11}$ der har en del elementer i sit jødiske forfatter- og privatliv til fælles med Roth, har denne i metafiktionens stadigt mere eksperimenterende form behandlet en del af de temaer, der lå i Portnoys genvordigheder, og en del af de problemer, som reaktionen på den rejste: modsætningen mellem pænhed og oprør, ægteskab og Don Juanisme, lov og lyst, den jødiske forfatters forhold til historien og familien, kunstnerens splittelse mellem ærlighed og hensynsfuldhed, æstetik og etik etc. Herigennem har han monomant, men fængslende, morsomt og dybt neurotisk, infantilt og samtidig meget intellektuelt belyst moderne jødisk identitet i stadigt vekslende historiske og kulturelle sammenhænge. 


\section{Noter}

1. Det jødiske gennembrud i amerikansk litteratur har jeg behandlet udførligt i min disputats Den moralske Don Juan - Om det jødiske gennembrud $i$ amerikansk litteratur. Borgens forlag, 1994.

2. Den danske udgivelse blev spaltet op i to bøger: Farvel, Columbus fra 1965 og de resterende noveller i Jødernes omvendelse og andre noveller fra 1972.

3. Jvfr. Ruth R. Wisse: The Schlemiel as Modern Hero, 1971, s. 119.

4. Roth har selv beskrevet arbejdet med romanen i essayet "In Response to Those Who Have Asked Me How Did You Come to Write That Book, Anyway", (1974) i samlingen Rending Myselfand Others, 1975.

5. I den danske oversættelse, som der fremover vil blive citeret fra, s. 243.

6. Jeg har mere udførligt behandlet denne teori i Den moralske Don Juan, s. $20 \mathrm{f}$.

7. Genoptrykt i Isaac Rosenfeld: Preserving the Hunger. An Isaac Rosenfeld Reader, 1988, s. 156-61.

8. Kafka har Roth mere eksplicit beskæftiget sig med i romanen The Professor of Desire, 1977, og i essayet "I Always Wanted You to Admire My Fasting; or, Looking at Kafka", 1972; i: Rending Myself and Others, 1975. Også i novellaen The Prague Orgy spores Kafka.

9. Essayet er genoptrykt i Howe: The Critical Point: On Literature and Culture, 1973. Kritik af romanen findes også i bl.a. Allen Guttrnann: The Jewish Writer in America, 1971, og Louis Harap: In the Mainstream. The Jewish Presence in Twentieth Century American Literature, 1950s-1980s, 1987. 10. Jvf. Mark Schechner: After the Revolution. Studies in the Contemporary Jewish-American Imagination, 1987, s. 207.

11. Det drejer sig om: The Ghost Writer, 1979; Zuckerman Unbound, 1981; The Anatomy Lesson, 1983, og The Prague Orgy, 1985. I 1986 blev disse 4 bøger udsendt i et bind under titlen Zuckerman Bound, A Trilogy and Epilogue. Zuckerman genopstår som roman-hovedperson i The Counterlife, 1987 og som biperson i Roths SI'!lvbiografi over ungdomsårene, The Facts. A Novelist's Autobiography, 1988. Endelig spiller han en mindre rolle i Roths allernyeste roman fra foråret 1997, American Pastoral. 